\title{
Head sweat rate prediction for thermal comfort assessment of bicycle helmets
}

\author{
Peter Bröde ${ }^{1,6^{*}}$, Guido De Bruyne ${ }^{2,6}$, Jean-Marie Aerts ${ }^{3,6}$, Tiago S Mayor ${ }^{4,6}$, Dusan Fiala, ${ }^{5,6}$ \\ From 15th International Conference on Environmental Ergonomics (ICEE XV) \\ Portsmouth, UK. 28 June - 3 July 2015
}

\section{Introduction}

Only $1 \%$ to $40 \%$ of adult cyclists in European countries make use of bicycle helmets. This may be partly attributable to impaired thermal comfort associated with helmet use, which can lead to locally accumulated sweat and increased skin wettedness [1]. Local sweat rates (LSR) can be modelled by sudomotor sensitivities (SUD) relating the change in LSR to the change in body core temperature (TC) [2], or by the ratio of LSR to gross sweat rate (GSR) of the whole body [3]. Coupling those local models with models of thermoregulation predicting TC and GSR provides a framework for predicting head sweat rates in response to the characteristics of the thermal environment, clothing, level of activity and exposure time. This paper studies the influence of different local and whole-body models on predictive accuracy.

\section{Methods}

We identified six different local models for the head region relying on SUD [2-4] and three models using LSR to GSR ratios [3]. These were linked with the models "Predictive Heat Strain" (PHS) [5], the multi-node UTCIFiala model of thermoregulation [6] and the still more complex "Fiala thermal Physiology and Comfort" (FPC) model [7]. We compared the prognoses to published means with 95\% CI of LSR measured at the frontal and lateral head during bicycle ergometer trials with varying air temperatures $\left(16-28^{\circ} \mathrm{C}\right)$, air velocities $\left(0.1-3 \mathrm{~m} \cdot \mathrm{s}^{-1}\right)$ and activity levels (power output $50-150 \mathrm{~W}$ ) [8,9].

\section{Results}

Models based on SUD overestimated frontal head LSR, whereas for two SUD models predicted lateral LSR were

\footnotetext{
* Correspondence: broede@ifado.de

${ }^{1}$ Leibniz Research Centre for Working Environment and Human Factors (IfADo), Dortmund, Germany

Full list of author information is available at the end of the article
}

within the experimental 95\% CI, but with absolute percentage error between 3\% and 36\%. GSR based predictions were lower than LSR from SUD and covered better the $95 \%$ CI for the forehead, but again error ranged from $8 \%-30 \%$. Though PHS gave less accurate predictions than UTCI-Fiala and FPC, the local model determined overall performance, which was best for one GSR and two SUD models $[3,4]$.

\section{Discussion}

The poor prediction of forehead LSR, especially by models using SUD, may be improved by considering the modifying effect of local convective cooling [10], which is relevant to cycling.

\section{Conclusion}

Eventually, integrating head LSR prediction with the calculation of skin wettedness in relation to evaporative resistance will provide assessment criteria for the thermal comfort of bicycle helmets.

\footnotetext{
Authors' details

${ }^{1}$ Leibniz Research Centre for Working Environment and Human Factors (IfADo), Dortmund, Germany. ${ }^{2}$ University of Antwerp, Belgium. ${ }^{3} \mathrm{KU}$ Leuven, Belgium. ${ }^{4}$ EMPA, St. Gallen, Switzerland. ${ }^{5}$ Ergonsim, Marxzell, Germany. ${ }^{6}$ HOPE-Helmet OPtimization in Europe, EU COST Action TU1101 Working Group 4 with the participation of JM Aerts, SA Annaheim, CP Bogerd, P Bröde, G De Bruyne, AD Flouris, K Kuklane, TS Mayor, RM Rossi (http://www. bicycle-helmets.eu.
}

Published: 14 September 2015

\section{References}

1. Bogerd CP, Aerts JM, Annaheim S, Bröde P, de Bruyne G, Flouris AD, Kuklane K, Sotto Mayor T, Rossi RM: A review on ergonomics of headgear: Thermal effects. Int J Ind Ergon 2015, 45:1-12.

2. Machado-Moreira C, Wilmink F, Meijer A, Mekjavic I, Taylor N: Local differences in sweat secretion from the head during rest and exercise in the heat. Eur J Appl Physiol 2008, 104:257-264. 
3. Smith CJ, Havenith G: Body mapping of sweating patterns in male athletes in mild exercise-induced hyperthermia. Eur J Appl Physiol 2011, 111:1391-1404.

4. Taylor NAS, Machado-Moreira CA: Regional variations in transepidermal water loss, eccrine sweat gland density, sweat secretion rates and electrolyte composition in resting and exercising humans. Extreme Physiology \& Medicine 2013, 2:4.

5. ISO 7933: Ergonomics of the thermal environment - Analytical determination and interpretation of heat stress using calculation of the predicted heat strain. Geneva: International Organisation for Standardisation; 2004.

6. Fiala D, Havenith G, Bröde P, Kampmann B, Jendritzky G: UTCI-Fiala multinode model of human heat transfer and temperature regulation. Int $J$ Biometeorol 2012, 56:429-441.

7. Fiala D, Psikuta A, Jendritzky G, Paulke $S$, Nelson DA, van Marken Lichtenbelt W, Frijns AJ: Physiological modeling for technical, clinical and research applications. Frontiers in Bioscience 2010, S2:939-968.

8. De Bruyne G, Aerts JM, Van der Perre G, Goffin J, Verpoest I, Berckmans D: Spatial differences in sensible and latent heat losses under a bicycle helmet. Eur J Appl Physiol 2008, 104:719-726.

9. De Bruyne G, Aerts JM, Sloten JV, Goffin J, Verpoest I, Berckmans D: Transient sweat response of the human head during cycling. Int I Ind Ergon 2010, 40:406-413.

10. Nadel ER, Bullard RW, Stolwijk JA: Importance of skin temperature in the regulation of sweating. J Appl Physiol 1971, 31:80-87.

doi:10.1186/2046-7648-4-S1-A85

Cite this article as: Bröde et al: Head sweat rate prediction for thermal comfort assessment of bicycle helmets. Extreme Physiology \& Medicine 2015 4(Suppl 1):A85.

\section{Submit your next manuscript to BioMed Central and take full advantage of:}

- Convenient online submission

- Thorough peer review

- No space constraints or color figure charges

- Immediate publication on acceptance

- Inclusion in PubMed, CAS, Scopus and Google Scholar

- Research which is freely available for redistribution

Submit your manuscript at www.biomedcentral.com/submit 